\section{THE SCIENCE AND TECHNOLOGY PROGRAM FOR HOMEMAKERS AT THE SOCIETY LEARNING CENTRE (PKBM) IN PADANG}

Jurnal Pendidikan Luar Sekolah

http://kolokium.ppj.unp.ac.id/ Jurusan Pendidikan Luar Sekolah Fakultas Ilmu Pendidikan Universitas Negeri Padang Sumatera Barat, Indonesia

Volume 6, Nomor 2, Oktober 2018 DOI: 10.5281 /zenodo. 1471727

\author{
Hayatunnufus', Wirdatul 'Aini',3 \\ ${ }^{1}$ Fakultas Pariwisata dan Perhotelan Universitas Negeri Padang \\ ${ }^{2} J u r u s a n$ Pendidikan Luar Sekolah Fakultas Ilmu Pendidikan Universitas Negeri Padang \\ ${ }^{3}$ Email: wirdatulaini@fip.unp.ac.id
}

\begin{abstract}
This community service was because many homemakers had much free time, but they did not yet have productive activities that could help adding the family income. Therefore, they were put in a program and trained to sew bajukurung. The aim was to have the women skillfully so that they were motivated to work hard and eager to open their own sewing business. The participants of the program were 17 homemakers living at Parupuk Raya Air Tawar Barat. The methods used in the program were: a) counseling; it was to prepare the participants to have a motivation, passion and characters, b) experiment; used to train the participants to be skillful in sewing bajukurung, begin with the measurement, cutting, and then sewing. The outcomes of the programs were having the participants informed and trained, the instructors helped them and showed them ways to sew. The training had been conducted. The participants could do measurement; they could draft the patterns, cut the cloth and sew it to be bajukurung.
\end{abstract}

Keywords: Science and Technologi, Homemakers, Society Learning Center

\title{
INTRODUCTION
}

Along with the growth of technology; transportation, information, trading system, human are faced with more demands, dealing with more changings, and required to fulfill more needs. More and more people are keen to have extra income to pay for all daily costs. More and more women are now shifting their positions in the family; from traditional into something which is regarded modern. Before, people believed that women were responsible for giving a birth, taking care of the houses, husbands and looking for the children. While, in a modern era, women are demanded to be educated, skillful, active and be able to play in two different roles; being a working mother. A woman has to help to add family income (Cleves, 2004).

Based on data obtained from the head of PKBM Cahaya Ilahi on February 27th, 2016, at Parupuk, it was found that many homemakers had free times while the husbands' incomes could not yet cover all the family needs. In fact, the living costs raised. Shorty, this had been a problem for the majority of the family.

In order to cope with the problem, one of the possible solution proposed is to provide the homemakers with certain skills through non-formal education activities. It is expected that 
the skills help the women to earn their own income. One of the foundations that role as government partnership program is PKBM.

The PKBM are important in assisting homemakers to be occupied with more skills. Based on the needs analysis, it was found that 17 homemakers are keen to improve their ability in sewing baju kurung (A traditional women dress in West Sumatera). The community service team of UNP selected the PKBM Cahaya Ilahi and PKBM Anarvani as the partnershipfoundations in implementing the training program for sewing Baju Kurung.

The contribution of non-formal education in empowering society is clearly seen from the definition and the nature of non-formal education itself. According to Coombs \& Manzoor (1984), non-formal education is an organized education, administered informally, an important part of an event which is meant to provide services for a community, to help them achieving certain learning outcomes. From the definition, it is possible to elaborate the roles of a nonformal education: a) the nature of non-formal education is to make the community study informally, b) the learning activity in non-formal education is intentionally and organized systematically to achieve particular goals, c) in line with its function, the target of non-formal education is all society, d) the non-formal education aims at giving knowledge, occupying skills, attitudes, that are helpful to develop human resources as national development capital.

Sudjana (1993) explains the roles of non-formal education are: a) to make the society study so that they have more skills, knowledge, attitude, values and aspiration to anticipate the coming problems in the future, b) to help the society to improve and use the natural resources in order to improve their living standard.

Moreover, Kindervatter (1979) clearly explains the roles of non-formal education is to empower. The non-formal education is not only to change the individual, but also groups, organizations, and societies. The non-formal education is an empowering process that covers knowledge, attitudes, skills and development improvement. In addition, Ibnu Syamsi (2010) says that the roles of non-formal education is an empowering process that includes the changing of human recourses, to make them be more developed society and the environment.

The success of an empowering process through non-formal education depends on the following phases: a) each individual is trained to be more sensitive to the social, economic, and politic development, b) each individual is trained or given various skills as an answer for the current demands, c) each individual is assisted to work in a team solving a problem (Noor, 2011).

Based on the previous explanation, it is seen that non-formal education covers providing needed skills to a society. In the regulation UU no.20 the year 2003, Sidiknas section 26 verse 4 and 5; that the units of non-formal educations are institutions, courses, training courses, group works, PKBM, majlis ta'lim. The training is administered to the society that needs knowledge, skills and attitudes to improve themselves, to develop the profession, and to work and to run independent business.

PKBM is an education institution that realizes the importance of society for the development of non-formal education. Therefore, the PKBM is expected to help to empower the potentials society. Sihombing (2002) explains that PKBM is an alternative to empower people. Through PKBM, it is possible to dig and improve more talents from the society, Unicef \& Unesco (2006) states that PKBM is an educational institution which is administered 
informally to help people to empower their powers, talents, by developing various learning models so that they can raise their living standard.

PKBM is a government partnership program that aims to educate the nations through its non-formal education programs, expected to grow a learning society so that later, the society can improve their independence, knowledge, and innovation in search of living standard improvement.

As a learning center, PKBM is based on the society needs that focus on teamwork and participation. The activity relates to the improvement of skills, abilities, and intelligence. If the non-formal education programs are selected as one alternate strategy in developing society, the PKBM is the medium to actualize education programs, to actuate the skills.

PKBM is the basis of society education that needs to be developed comprehensively, flexible, various, and open for all ages in line with the roles, the desires, interests, and needs of the society.

\section{METHODS}

The activity was done in two forms; counseling and training. The counseling is aimed at occupying the homemakers with strategies so that they can grow their own motivation to develop their skills. The method used to assist the women were lecturing method, asking and answering questions and discussion. While, the training was done to improve the skills of the women in sewing baju kurung.

The success of the program is seen from the process and the results. The process was evaluated by paying attention to the intensity, creativity and enthusiasm of the participants. The technique used to evaluate the process was observation, and administration (the attendance of the participants)

From the aspect of skills, it was evaluated by paying attention to the result of the training of sewing baju kurung. From the theoretical aspect, the test was done in order to see how well the participants understood the materials; such as measuring the body, designing the patterns, cutting and sewing.

\section{FINDINGS AND DISCUSSION}

The findings obtained from the training consisted of two aspects: 1) the training that was related to the skills obtained by the participants, and 2) the description of the findings related to the participants' understandings towards the aims of the training, the methods, the materials, the facilities, and the instructors. Details description of the training is described as follows:

\section{The Training}

Based on the observation during the training, the participants were found to be serious in following the activities, the participants actively attended the classes to learn sewing bajukurung. This data were proven from the participants' attendance which was nearly $100 \%$.

The outcomes were: 1) the participants were able to measure a person's body before the started to sew; almost $90 \%$ of the participants were able to do this. 2) $90 \%$ of the 
participants were able to change patterns along with its designs, the participants could design the patterns of bajukurung, even, some of them could elaborate the design, and made a draft of a gamis. 3) $80 \%$ of the participants could cut the cloth, 4) $90 \%$ of the participants could sew.

At the end of the programs, each participant could show one finished-bajukurung. As the follow-up for the program, it was expected that the PKBM could continue the activity by keeping the participants motivated to improve their skills, therefore, in the future, they would have a productive activity which helps their husbands earned.

\section{The Participants' Perception of the Program}

Based on the activities done during the program, the team also evaluated related aspects; they are:

\section{The Aims of the Program}

Seen from the aims of the program, the participants stated that they followed the program since they would like to obtain knowledge and skills on how to sew clothes. Around $70 \%$ of the participants agreed that by following the program they would get knowledge, while the other $30 \%$ agreed that the aims were to show how to sew clothes. Besides, the participants followed the program was to have them skillful in sewing, $82 \%$ of the participants strongly agreed, and other $18 \%$ of the participants agreed. Moreover, related to another aim of the program, that was to help improve family income, 65\% strongly agreed with the statement, while the other $35 \%$ agreed.

Beside the fact that the participants followed the programs in order to get knowledge and skills, in the future, the skills would always be needed, therefore, $53 \%$ of the participants strongly agreed to be entrepreneurs, to support the family income by sewing and then selling clothes, while the other $47 \%$ agreed. Then, the participants who were housewives could have an alternative activity to do when they were in their leisure time. $65 \%$ of the participants strongly agreed with the statements, while the other 35\% agreed.

The aims of the programs were the primary phases that needed to be formulated before they were conducted. The aims should be formulated before the program was administered. According to Bloom (Uno, 2007) stated that the aims should cover three aspects; cognitive, affective and psychomotor. Through the programs, the three aspects were things to be achieved. The program done by the community service team was to prepare the participants to run their own business in the future.

\section{The Training Materials}

In this part, the participants' perception about the program related to the materials given by the instructors both theoretically and practically. The materials presented covered their needs. $65 \%$ of the participants strongly agreed with the statement, while the other 35\% agreed. Seen from the aspect of the use of materials, $76 \%$ of the participants claimed that they strongly agreed, that the materials were useful, while the other $24 \%$ agreed. The instructors presented the materials that the participants needed to understand. $83 \%$ of the participants strongly agreed, and the other 17\% agreed. Then, the participants were keen to follow the programs. $53 \%$ of the participants strongly agreed, the $47 \%$ of the participants agreed. The participants' attendance was nearly $90 \%$. 
The Science and Technology Program for Homemakers...

Then, the materials presented by the instructors were theoretically understood by the participants. $47 \%$ of the participants strongly agreed, the $53 \%$ of the participants agreed. Related to the materials practically, $53 \%$ of the participants strongly agreed that they understood the materials practically, the other $47 \%$ of the participants agreed. After the program finished, $59 \%$ of the participants strongly agreed that they were skillful, the other $4 \%$ agreed.

The materials were a set of learning materials provided and given to the students during the program. The learning materials were a combination of materials for knowledge, skills, and attitudes. According to Wina (2008), the materials were things discussed during the program, it could be information transferred in form of knowledge, skills, and attitudes. The criteria of materials were: a) the content should be easy to be understood, b) the content should be interesting, encourage the participants to learn more. The learning materials in sewing bajukurung met the students' needs.

\section{The Training Methods}

Seen from the experimental method used by the instructors were helpful for the students in sewing the clothes. $82 \%$ of the participants strongly agreed with the statement, the other $18 \%$ agreed. Then, the presentation of the materials was understandable; $47 \%$ strongly agreed, the other $53 \%$ agreed. The materials related to cutting the clothes, sewing were considered helpful, $76 \%$ said that they were strongly agreed while the other $24 \%$ of the participants agreed.

According to Wina (2008), learning method was ways used to implement the plans in order to achieve the aims of the program. The method used depended on the materials and the aims. If the aims were to have the participants skillful in an activity, the method used was the experimental method. Yet, if the aims were to give counseling, then the method was lecturing and asking and answering questions. In the program, the aims were to have the participants able to sew baju kurung, therefore, the method was demonstration and experiment.

\section{The Instructors of the Program}

It was said that the instructors helped the participants when the participants did not understand the materials, $65 \%$ of the participants strongly agreed with the statement, while the other $35 \%$ of the participants agreed.

Then, the instructors were one factor that had an important role in the successful of the program. Based on the perception given by the participants toward the instructors, it was found that $65 \%$ of the participants strongly agreed that the instructors explained the theory of cutting the cloth and sewing bajukurung, while the other 35\% agreed. Then, the instructors were friendly; 59\% strongly agreed, $41 \%$ agreed. The instructors could work together with the participants; $59 \%$ of the participants strongly agreed; $41 \%$ agreed.

Learning sources were all good things that could be used as materials for the participants. Human resources were the primary sources in the program Learning sources were those who were expertise in a particular field. Yusuf (Sudjana, 1993), the criteria of learning sources were: a) contain knowledge, skills, and attitudes; b) have non-formal education learning strategies and able to choose the appropriate materials, c) able to manage the non-formal education, d) well-behave. The learning sources for sewing bajukurung training had skills in sewing. 


\section{The Learning Facilities and Husbands' Supports}

The factors supported the participants following the program were the availability of the facilities, learning sources, the team, the materials needed; cloth, needles, sewing machine. The facilities could be used by the participants.

The supports given by the family and husbands were seen from how the participants were supported. $82 \%$ of the participants strongly agreed that they were supported by their husbands to follow the program, while the other $18 \%$ agreed. Then, the participants wanted to open their own sewing business, $76 \%$ strongly agreed and $24 \%$ agreed. In addition, $29 \%$ of the participants strongly agreed that their husbands supported their will to run a business, while the $71 \%$ agreed.

The facilities were important components in the teaching and learning process. The facilities were directly related to the continuity of the program. Arif (1989) stated that the learning facilities were things used directly during the learning process. In the program conducted, the facilities provided included the cloth, the sewing machine, and other things needed to sew bajukurung.

\section{The Study Room}

The availability of the place was another supporting factor. The program was conducted at PKBM Cahaya Ilahi Parupuk Tabing Padang. The location was representative since it was far from the main road. Therefore, the place was quiet. $41 \%$ of the participant strongly agreed to say that the place was representative, while the other $59 \%$ agreed. The air circulation in the study room was fine. $29 \%$ of the participants answered strongly agreed and $71 \%$ answered agreed. Then, the size of the room was enough for 17 participants. $47 \%$ of the participants strongly agreed and 53\% of the participants answered agreed.

The study room was an important factor in the program. Mappa (1984) stated that study rooms should be selected based on the following requirements: a) the place was in a strategic location, b) the room could handle 5-20 participants, c) the settings of the equipment used could be rearranged, d) the air circulation was good, e) the lighting was representative, f) the room was not around the main roads which were often noisy.

\section{CONCLUSION AND SUGESTIONS}

\section{Conclusion}

Based on the activities done during the program, the possible conclusions made were: 1) the participants had high motivation to follow the program; it was seen from their attendance. 2) the aims of the program was to have the participants skillful in sewing bajukurung, so that they could open their own sewing business. 3) the materials presented by the instructors met the participants' needs. The materials were useful. 4) the participants were able to do a measurement, draft the patters, elaborate the theory, cut the cloth and sew the cloth. 5) the participants understood the values of characters as supporting aspects such as discipline, hard work, and passion. 6) the availability of the facilities of the sewing bajukurung program. 7) most of the participants had the intention to run their own sewing business to help the family income.

\section{Suggestions}


The Science and Technology Program for Homemakers...

It is expected that the participants of the programs keep practicing so that they are even more skillful in sewing. It is expected that the participants are eager to start opening their own sewing business, that way, they can help the family income. Then, it is expected that the PKMB always assists and motivates the participants to be more independent and have their own business.

\section{REFERENCES}

Arif, Z. (1989). Pengembangan Program Latihan Modul 5-9. Jakarta: Universitas Terbuka.

Cleves, M. (2004). Gender dan Pembangunan. Yogyakarta: Rifka Annisa.

Coombs, P., \& Manzoor, H. A. (1984). Memerangi Kemiskinan di Pedesaan Melalui Pendidikan Nonformal. Jakarta: Rajawali.

Kindervatter, S. (1979). Nonformal Education as an Empowering Process. Massachusetts: Center for International Education University of Massachusetts.

Mappa, S. (1984). Pengelolaan Kelompok Tempat Kegiatan Belajar PLS. Jakarta: Depdikbud Dirjen PT P2 LTK.

Noor, M. (2011). Pemberdayaan Masyarakat. Jurnal Ilmiah CIVIS, I(2), 87-99. Retrieved from https: / $/$ www.google.com $/$ url? sa $=\mathrm{t} \& \mathrm{rct}=\mathrm{j} \& \mathrm{q}=\&$ esrc $=\mathrm{s} \&$ source $=$ web\&cd $=2 \& \mathrm{cad}=\mathrm{r}$ ja\&uact $=8 \&$ ved $=2$ ahUKEwj_lMGroaLeAhWJOY8KHb15DA8QFjABegQIBxAC \&url $=$ http $\% 3 \mathrm{~A} \% 2 \mathrm{~F} \% 2 \mathrm{Fjournal.upgris.ac.id} \% 2$ Findex.php $\% 2 \mathrm{Fcivis} \% 2 \mathrm{Farticle} \% 2 \mathrm{~F}$ download $\% 2$ F591\%2F541\&usg=AOvVaw2U7BXju55QZ5CPlnpfB6uH

Sihombing, U. (2002). Menuju Pendidikan Bermakna Melalui Pendidikan Berbasis Masyarakat. Jakarta: CV. Multiguna.

Sudjana, D. (1993). Strategi Pembelajaran dalam Pendidika Luar Sekolah. Bandung: Nusantara Press.

Syamsi, I. (2010). Pendidikan Luar Sekolah Sebagai Pemberdaya Masyarakat. Diklus, 14(1), 6676.

Retrieved from https://journal.uny.ac.id/index.php/diklus/article/download/5796/5002

Unesco. (2015). Asia-Pacific Regional Education for All Report: A Synthesis of the National EFA Report. (P. Bergstrom, Ed.). Paris: United Nations Educational, Scientific and Cultural Organization. Retrieved from http://unesdoc.unesco.org/images/0023/002332/233236E.pdf

Uno, H. B. (2007). Model Pembelajaran Menciptakan Proses Belajar Mengajaryang Kreatif dan Efektif. Jakarta: Bumi Aksara.

Wina, S. (2008). Kurikulum dan Pembelajaran. Jakarta: Kencana Prenada Media Group. 